\title{
Foreign Capital Investment into Developing Countries: Some Economic Policy Issues
}

\author{
Kalim Siddiqui ${ }^{1}$ \\ ${ }^{1}$ The Business School, University of Huddersfield, Queensgate, Huddersfield, UK \\ Correspondence: Dr. Kalim Siddiqui, The Business School, University of Huddersfield, Queensgate, Huddersfield, \\ HD1 3DG, UK. E-mail: k.u.siddiqui@hud.ac.uk
}

Received: March 16, 2015

Accepted: April 10, 2015

Online Published: May 5, 2015

doi:10.5430/rwe.v6n2p14

URL: http://dx.doi.org/10.5430/rwe.v6n2p14

\begin{abstract}
This paper analyses the role of foreign capital in the economic development of developing countries, particularly South Asian and East Asian countries. Mainstream economists suggest that foreign investment would benefit developing countries by increasing the availability of capital, and through their positive impact over productivity and the general economic wellbeing of the host country. After the Second World War, the rapid economic growth first of Japan and later on of South Korea, Hong Kong, Singapore, and Taiwan has been widely cited in support of foreign capital. It is true when we look at the records in terms of the removal of poverty, job creation, educational achievements and improving the overall living conditions.

I find however, that such discussions have ignored the experiences of developed countries in their early phase of industrialisation. In addition there is a lack of attention to the analysis of the issue of capital inflows in the context of neoliberal economic reforms and financial deregulation. After the global financial crisis in 2008, capital inflows to developing countries have witnessed a sharp decline. Foreign investments are highly sensitive to foreign exchange rate fluctuations. Thus, under such a situation, it is difficult to build a long term industrialisation strategy
\end{abstract}

Keywords: foreign direct investment, economic liberalisation, developmental issues

\section{Introduction}

This article examines the extent to which foreign capital may or may not be contributing to the development of the economies of developing countries (Note 1). Mainstream economists and international financial institutions indicate that the foreign investment in developing countries would benefit those countries by increasing the availability of capital and thereby having a positive impact over productivity and the general economic wellbeing of the host country. Alfaro et al. (2004) examine the link between capital inflows, financial development and economic growth. They argue that countries with developed financial markets are able to attract capital inflows more efficiently. According to them, "the potential of FDI (foreign direct investment) to create backward linkages in the absence of well-developed financial markets is severely impeded". (Alfaro, et al, 2004:92)

On the importance of foreign capital, an International Monetary Fund study states: "These flows and capital mobility more generally, allow countries with limited savings to attract finance for productive investment projects foster the diversification of investment risk, promote intertemporal trade, and contribute to the development of financial markets". (IMF, 2010a)

This paper is organised as follows: Section 1 presents a brief introduction. The section 2 analyses the past experiences of inflow of capital in the developed economies. Section 3 looks at the foreign capital and the developmental issues. Section 4 discusses the role of the foreign capital in East Asia. Section 5 examines the recent experiences of inflow of capital in India and finally conclusion section summarises the findings.

The proponents of foreign capital argue that foreign capital can supplement domestic investment and thus lead to higher growth rates. It can also reduce the potential balance of payments constraints on growth. Foreign companies contribute to the technological base in the developing countries' economies, and through technological and organisational spillovers, could raise the productivity and competitiveness of the host economy, while the critics argue that foreign firms can introduce inappropriate technology and products, and aggravate balance of payments problems due to high remittances and capital flows. 
Broadly two arguments have been put forward. Firstly, it is said that capital inflows to developing countries are largely influenced by factors from the supply-side. The government's pro-market reform policy will encourage foreign investors to invest. Secondly, the easy monetary policies in the developed countries (Note 2) encouraged the exporting of capital into developing countries. This is largely due to easier and larger access to liquidity. It is expected that in developing countries the returns would be higher. In a situation when monetary policies in developed countries are tightened, the differential falls and capital inflows can slow down and even start flowing in reverse.

Yet, further study of foreign capital investment is important because current discussions ignore the experience of developed countries in their early phase of industrialisation. There is also a lack of attention paid to the analysis of the issue of capital inflows in the context of neoliberal economic reforms and financial deregulation. We will argue that institutions are important and in their absence foreign capital investment might lead to increase in exports, but not necessarily increases productivity in the domestic firms. On the basis of recent official data and various studies, the study will critically examine the capital inflows, particularly in South and East Asia over the past three decades.

The growth experience of East Asia has received world-wide attention. This is because East Asia is seen as a new centre for growth and can be a lesson for other regions. Also, these economies' greater reliance on trade and foreign capital to achieve economic growth rates has been widely discussed. (Michie, 2011; Alfaro et al, 2004) The rapid economic growth in East Asian economies is presented as evidence in favour of export-led growth, economic liberalisation and greater economic integration with the Western economies. After the Second World War, the rapid economic growth first of Japan and later on of South Korea, Hong Kong, Singapore, and Taiwan has been widely cited in support of foreign capital investment. This is verified when we look at the records in terms of the removal of poverty, job creation, educational achievements and improving the overall living conditions.

Until the early 1990s, East Asian countries have maintained government control over capital inflow and outflows. Japan during the post-war boom did not witness any FDI inflows. Korea and Taiwan did receive a large amount of foreign aid in the early period of their industrialisation, but did also rely on overseas borrowing. It is often claimed that foreign capital could play a vital role in achieving significant economies of scale with export promotion and by raising productivity. However, it is useful to analyse how East Asian countries have managed to achieve 'economies of scale', while at the same time protecting and promoting their domestic industries. As Chang (2006) argues, "[East Asian] governments have managed extensive regimes of regulation regarding entry and capacity in many industries with scale economy. The problem, however, is that, even with such controls, many domestic markets in many developing countries are still too small to fully realise scale economy. Given this, even when the hoped-for technological learning by the protected firms happens, it is very difficult for them to achieve internationally competitive levels of productivity, as they operate well below the minimum efficient scale....However, the East Asian policy makers often took different courses of action...they initially accepted sub-optimal production scales, but used a range of policy measures to bring forward the day when these firms could export and thus produce at more than the minimum efficient scales" (Chang, 2006:38-39).

However, in contrast to the Japanese growth process, Hong Kong, Taiwan, Singapore, South Korea had little domestic markets and relied heavily on foreign markets. Also the foreign companies, apart from Singapore and more recently China and Malaysia, have been less important in Japan, South Korea and Taiwan in their early years of industrialisation (Siddiqui, 2010a). On the question of exports, for instance, between 1960 and 1983, the rate of growth of South Korea's exports was twice as big as that of Japan. The experience from the East Asian crisis of 1997 seems to be a crucial lesson for others when it comes to relying on FDI for their development needs. For example, Malaysia after the 1997 crisis imposed capital controls, which resulted in less sharp economic decline, compared to Indonesia, South Korea and Thailand. These were the countries who adopted the IMF's prescription during the post-1997 period. As Tourk (2012) observes, "The 1997 crisis, on the other hand, was a result of an International Monetary Fund policy that reflected Wall Street interests. The US Treasury, in the 1980s, prodded the IMF to push for the immediate liberalisation of the capital account in emerging economies. Such advice ran against the grain of the literature on the sequence of economic reform". (Tourk, 2012)

\section{Importance of Foreign Capital: A Historical Overview}

It will be useful to analyse past polices in relation to foreign capital. Various studies clearly indicate that developed countries have discriminated against foreign investors while favouring domestic industries in the past (i.e. in the early phases of industrialisation). They had adopted a range of polices to build up domestic industries such as technological transfer, limits of ownerships, and insistence on joint ventures with local firms. However, once they became more mature and competitive, this was relaxed (Note 3). 
The United States, for example, between 1875 and 1914, was the world's largest importer of foreign capital. It was obvious that there was concern inside the country about "absentee management" and the foreign domination of the US economy. The Bankers Magazine of New York expressed these concerns in 1884 in these words: "It will be a happy day for us when not a single good American security is owned abroad and when the United States shall cease to be an exploiting ground for European bankers and money lenders. The tribute paid to foreigners is ...odious... We have outgrown the necessity of submitting to the humiliation of going to London, Paris or Frankfurt [sic] for capital has become amply abundant for all home demands". (Bankers' Magazine, No.38, January 1884, cited in Wilkins, 1989:565) Furthermore, on the question of the United States policy toward foreign investors in the early years of the country's industrialisation Chang (2004) has commented in these words: "In contrast to its [the US's] strong support for foreign investment liberalisation today, when it was a capital-importing country, the US had all kinds of provisions to ensure that foreigners invested in the country but did not control its economy. For example, the US federal government had restrictions on foreigners' ownership in agriculture land, mining, and logging. It discriminated against foreign firms in banking and insurance, while prohibiting foreign investment in coastal shipping. It demanded that all directors of national banks be American citizens, while depriving foreign shareholders of voting rights in the case of federally chartered banks". (Chang, 2004:693-94)

It appears that despite harsh regulations against foreign capital, the US was still the largest recipient of foreign capital. Similarly today, China is the largest recipient of foreign capital, despite various state regulations (Siddiqui, 2009). Also, in the UK, when Nissan invested in car manufacturing in 1981, it had to accept procuring $60 \%$ of its value added locally (Note 4). Japan has always had a restrictive policy towards foreign capital. During the early industrialisation (the Meiji period) years it discouraged foreign investors and if needed opted for technology licensing. After the Second World War, despite more openness compared to the past, foreign capital still played a small role and much of it was in joint ventures. In the mid-sixties, foreign ownership was limited to only $63 \%$, while in vital industries it was banned altogether. As a result, foreign capital in Japan accounted for only $6 \%$ of the total investment in the industrial sector until 1970. Japan has been the least FDI-dependent country among the developed countries, and between 1971 and 1995, FDI accounted for only about $0.1 \%$ of total fixed capital formation in the country.

The contribution of foreign capital in Korea's economy was only 5\% between 1963 and 1982. Despite the governments' pro-liberalisation policies towards foreign investors in the mid-1980s it reached only 9.7\%. (Amsden, 1989:92) The country's attitude towards foreign investors in the 1960s was designed on the basis of a very sophisticated notion of costs and benefits, with invitations to MNEs and foreign investors only approved after potential benefits were recognised. The government's 1981 White Papers on Foreign Investment lists that such investments should positively contribute towards industrial upgrading, technology transfer, job creation and balance of payments. (Amsden, 1989) There were policies that restricted areas where MNEs could enter. In the early 1980s, nearly $50 \%$ of all industries and $20 \%$ of manufacturing industries were still 'off-limits' to foreign investors. Even later when entry were allowed, joint ventures were encouraged and expected to facilitate the transfer of technologies and organisational skills to local partners.

\section{Foreign Inflow of Capital and Developmental Issues}

Developing countries, mainstream economists argue, require more economic integration through trade and investment in order to build a competitive and efficient economy (Siddiqui, 1994a). It is claimed that following such policies would lead towards a surge in exports and attract foreign capital investment to augment domestic savings. It would ultimately increase the overall domestic investment in developing countries. (IMF, 2010b) Further, it is said that many developing countries face shortages in domestic savings, trade imbalances and a foreign exchange crisis. It is assumed that in the absence of foreign capital, the shortages of external financing are likely to put constraints on the economic growth and living conditions of the people. It is claimed that failing to attract foreign capital implies that national income and living standards will be negatively affected. (IMF, 2010a)

The proponents of capital inflows also argue that foreign capital supplements domestic savings and increases the overall investment and rates of growth in the host country. However, foreign capital inflow is volatile and relies on various push and pull factors. The push factors include lower interest rates and declining marginal efficiency in the capital exporting countries, and also the presence of large amount of surplus capital. The pull factors from the host countries are due to the availabilities of higher interest rates compared to the capital exporting countries. The demand for capital may be another crucial full factor that attracts capital inflows. Calvo et al (1993) find that capital inflows in the 1980s in Latin America were basically driven by recession and the low interest rates in the United States. In developing countries the higher GDP growth rates have increased the demand for capital inflows.

The argument is that the inflow of capital benefits developing countries by increasing their investment rates above their savings. This is based on the argument that rich countries have abundant capital and developing countries lack capital (Siddiqui, 1994a). Therefore, if capital is allowed to move unrestricted across countries, then everyone will 
benefit. It is expected that the capital inflow from the rich countries would be invested in the poor countries. It is said that international capital mobility would promote economic growth and employment opportunities in developing countries.

However, after independence, most developing countries did not assign a major role for foreign capital in their economic development. Then it was widely believed by the policy makers that a strong inflow of foreign capital would undermine the independent industrialisation they would like to pursue. In fact, until the 1970s, the private international financial system played only a limited role in recycling financial surpluses to developing countries. Most of the capital flows to developing countries were through official bilateral and multilateral channels. However, at present, foreign capital is thought to be a positive but essential factor in order to achieve rapid growth and industrialisation. The oil surplus money from oil exporting countries and also the pension funds of developed countries were looking for higher returns. As a result, capital in the form of debt and equity investment began to flow into those countries, which were able to provide for both secure and higher returns.

Since the 1980s, various developing countries have been forced to learn about the power of finance. Thanks to international institutions, pressure for financial liberalisation to increase the inflows and outflows of capital (in debt and in stock markets) create boom and bust cycles that often bring uncertainty in the real economies. Moreover, we also find the governments of several developing countries looking nervously for signs of financial markets' approval and formulating polices to meet these expectations. Foreign capital is seen to be a vital source of investment that could affect growth. Hence, the government is expected to attract global capital and should also do everything to prevent capital outflows.

After the adoption of policies of economic liberalisation, the inflow of foreign capital into developing countries has risen sharply and currently accounts for a significant proportion of their national investment. Despite the fact that a large proportion of FDI goes into developed economies, the share of developing economies has increased to $21.4 \%$ in 2001 from 17.1\% in 2000 (UNCTAD, 2001:256). However, more than three-quarters of all the capital inflows go to 10 developing countries including China. In recent years the liberalisation of markets for goods, services and capital has encouraged a sharp increase in FDI and huge economic power has been transferred to the MNEs (Multinational Enterprises), compared to three decades ago. For instance, FDI inflows in global markets in 2008 were US\$1.7 trillion, propelled by MNEs and their affiliates. (IMF, 2010b)

The net capital inflows in developing countries have become much more volatile. Chart 1 shows net financial inflows to emerging and developing countries for the period of 1980 to 2010. As Chart 1 indicates, the net capital flows were small from 1980 to 1990 . However, financial inflows rose significantly during 1991-96, only to decline after the 1997 crisis to touch close to early-1990s levels by the end of the decade. The net amount rose again from 2002 to 2005. We find a sharp rise in 2006-2007. However, the net financial inflows declined sharply in 2008-2009, but rose between 2009 and 2010 (see Chart 1). The figure clearly indicates that the economic crisis in many developed countries does affect the amount of capital inflows into developing countries.

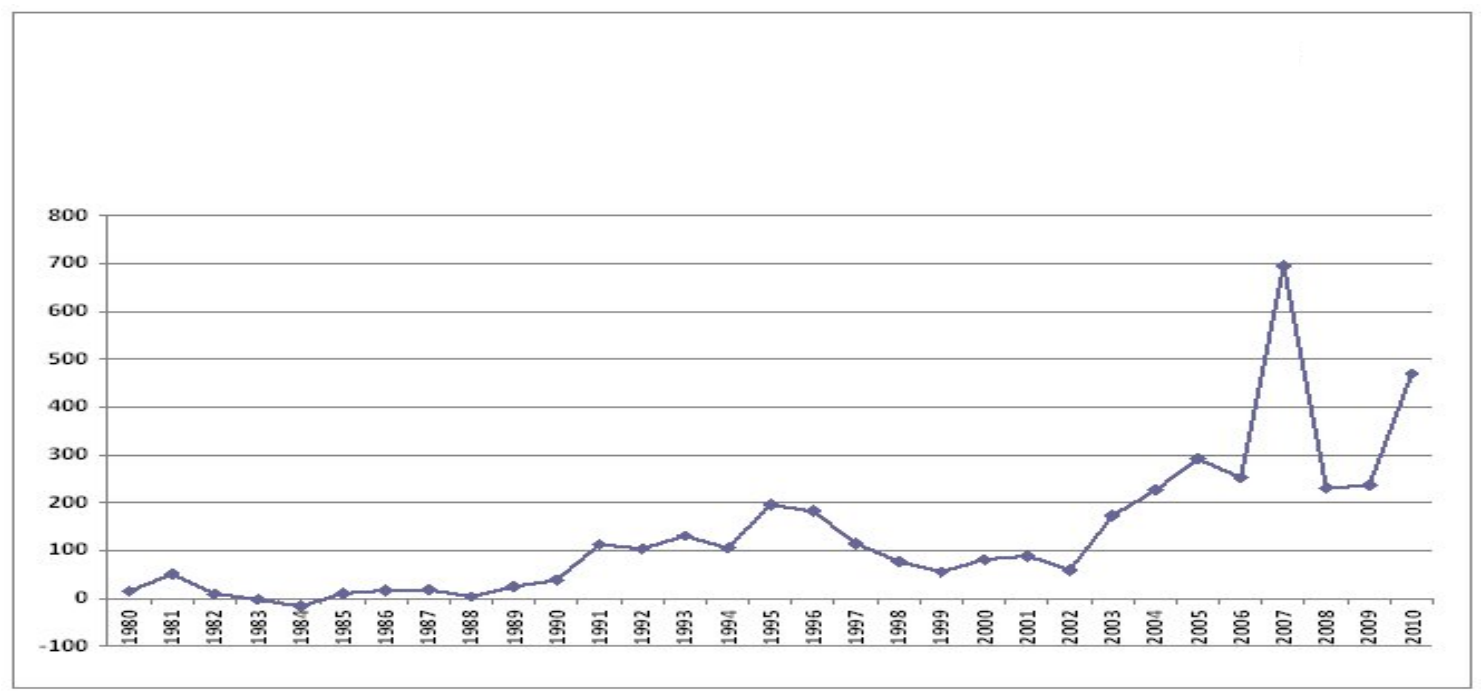

Chart 1. Net financial flows to emerging and developing countries (\$bn)

Source: World Economic Outlook, (2011) April. IMF, Washington D.C 
The composition of capital inflows is largely of two types: "private portfolio" and "other private" flows, with the latter including debt as shown in Chart 2. Chart 2 displays the data for the period of 1991 to 2010 about the composition of financial flows. During the last two decades direct investment has risen rapidly compared to private portfolio and other private financial flows. However, just before the global financial crisis of 2008 , foreign direct investment was at its largest compared to previous years. It declined in 2009 and again slightly rose in 2010, but still the total financial inflows were less than 2007. There has been much less fluctuation in the case of direct investment flows. However, after 2008 the size of direct investment has risen again. Private portfolio flows and other private financial flows have been negligible. However, direct net investment flows have been substantial enough to provide much cause for concern. The fact shows that foreign direct investment flows are differentially distributed across countries (with China taking a large share).

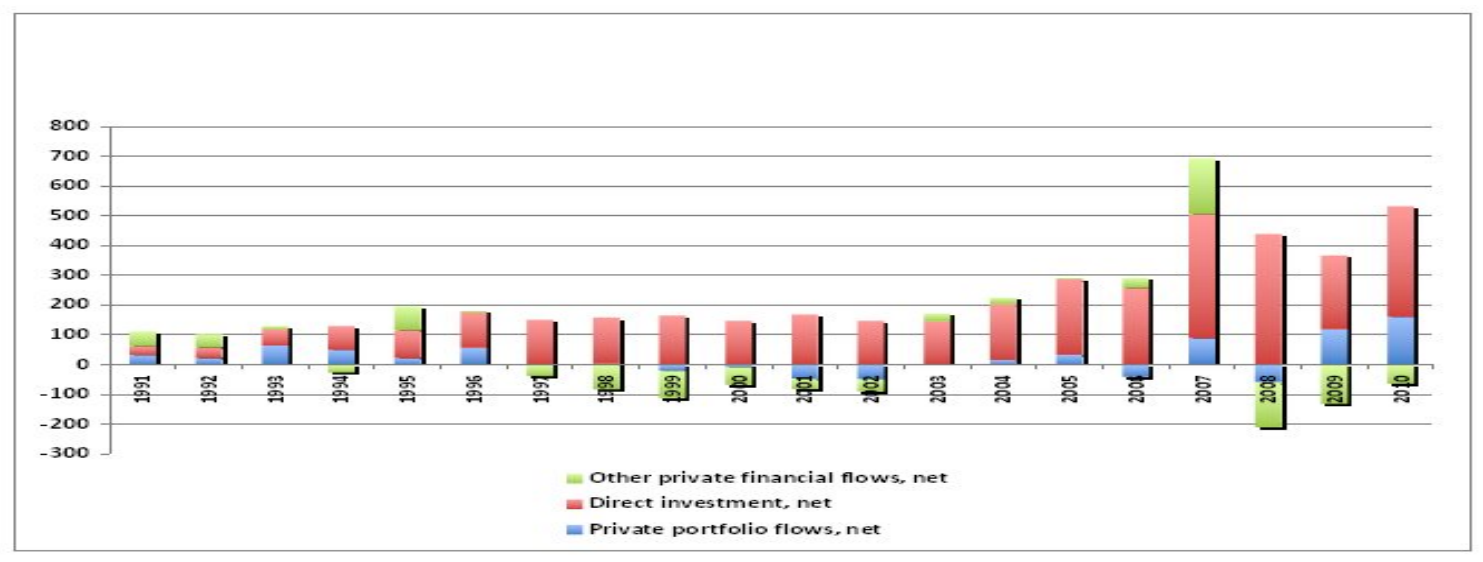

Chart 2. Composition of financial flows (\$bn)

Source: World Economic Outlook, (2011) April. IMF, Washington D.C

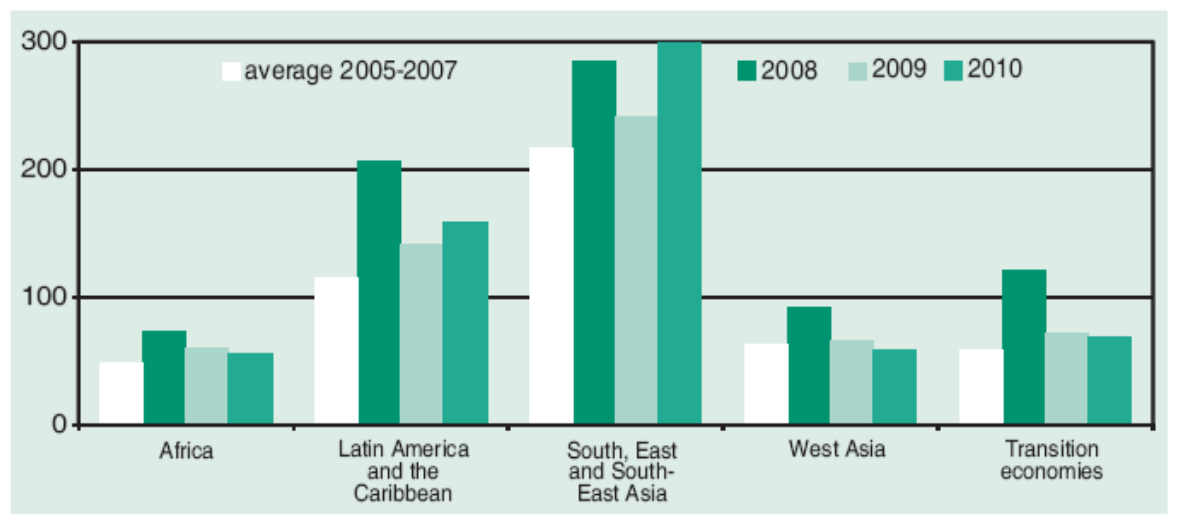

Source: UNCTAD, FDI/TNC database (www.unctad.org/fdistatistics).

Chart 3. FDI inflows into developing countries by regions (US\$ billion)

Chart 3 shows the distribution of FDI into different regions from 2005 to 2010. The East Asian region has been the largest recipient of capital inflows, while Africa has been the lowest recipient during this period. The FDI share of South Asia has risen compared to two decades ago. West Asia has also received a much smaller amount of FDI compared to Latin America and East Asia for the period of 2005-2010. Between 2005 and 2010 the FDI inflows for 
Africa similarly did not show much change. However, the FDI inflows into South and East Asia were much higher than any other regions among the developing economies for the same period, as shown in Chart 3.

Despite slow growth in the developed economies, the global capital inflows increased by $16 \%$ in 1911 to $\$ 1524$ billion up from $\$ 1309$ billion in 2010. In 2011 foreign capital inflows rose compared to 2009 in all economies. Emerging economies continued to attract nearly half of global inflows of capital. (UNCTAD, 2012) Capital inflows to Asian countries continued to increase; the main reason seems to be a strong growth in East Asia and South Asia. Two countries, namely India and China, witnessed capital inflows rise by $31 \%$ and $8 \%$ respectively (Siddiqui, 2014a).

Chart 4 shows the FDI data from 2000 to 2010 for various regions within Asia. Even though capital inflow increased into developing countries, all countries did not receive equal amounts. Countries with higher growth rates received a larger amount of inflow, while the countries with low growth rates received little inflow of foreign capital. For instance, the capital inflows were the largest for the East Asian region in 2000. While for South Asia, the capital inflows were very small in 2000, but grew rapidly from 2005. It seems that the inflows of capital to developing countries have risen because of their overall higher growth rates than developed countries. The global capital inflows as a proportion of the GDP are expected to decline from heights of about $3 \%$ of global GDP to an average of $2.5 \%$ in 2014. Moreover, capital inflows into developing countries are expected to decline from peaks of $4 \%$ of developing countries' GDP in 2007 to an average of about 3\% of their GDP in 2014. (IMF, 2011)

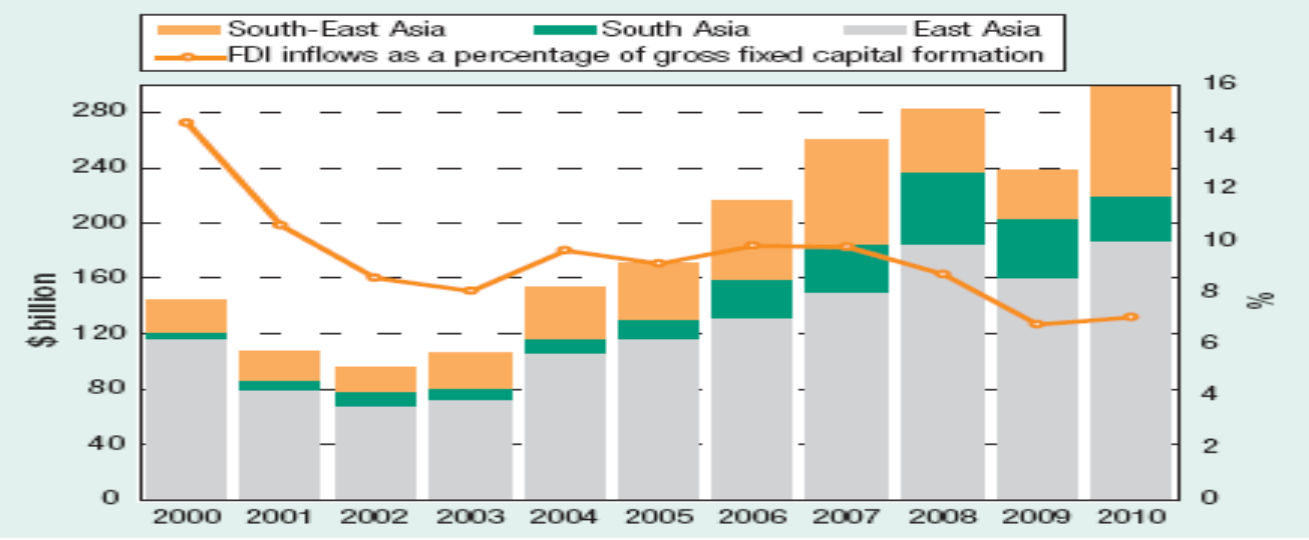

Chart 4. Inflows of FDI within Asian countries

Source: UNCTAD (2012) World Investment Report, Geneva: United Nations, Page 45

Chart 5 indicates that the USA was the largest recipient of foreign capital inflows in 2009 and 2010, while China was the second largest recipient after the USA for the same year. India has received a smaller amount of FDI, compared to for instance, Brazil for the same period (See Chart 5), despite, India's adoption of neo-liberal economic policies for the last two decades. Smaller countries like Singapore received a much higher amount of FDI compared to India in 2010 (Siddiqui, 2014a). It is said that inward foreign investment can stimulate clustering activities and will have spill overs in the overall economy. The clusters or firm agglomerations could play a positive role in building regional development. "Clusters have proved to combine a flexible organisation of production with high levels of specialisation and competence. This facilitates output quantity- flexibility and variety as required by a volatile demand". (De Propris and Driffield, 2006: 277) The government, which intends to link their economies closer to global markets with MNEs based FDI, has to offer financial incentives, and it is hoped that local businesses will benefit from the spillovers. Clusters are supposed to have the characteristic of a high degree of specialisation leading towards a high degree of competitiveness and are therefore able to attract foreign firms in their local decisions. In global production, an MNE does not carry out all production tasks, but splits itself among numerous firms, each of whom are designated to carry out a specific task. It is supposed to help them to reduce transaction costs. However, in recent years developments in IT technology and transportation costs have declined. For example, in the auto industry, the auto manufacturers concentrate on new models, product designs and operating systems, leaving the production of components details etc. to their suppliers. 


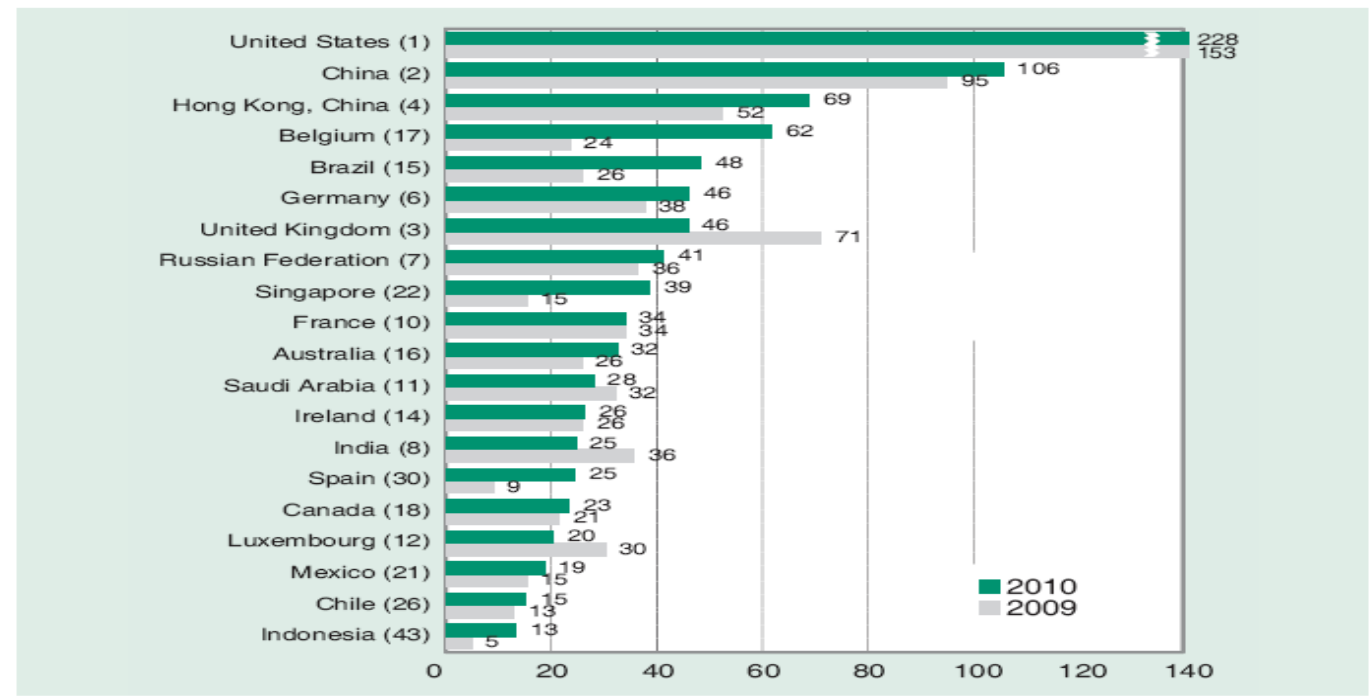

Source: UNCTAD, based on annex table I.1 and the FDI/TNC database (mww.unctad.org/fdistatistics). a Ranked on the basis of the magnitude of $2010 \mathrm{FDI}$ inflows.

Note: The number in bracket after the name of the country refers to the ranking in 2009 . British Virgin Islands, which ranked 12 th in 2010 , is excluded from the list.

Chart 5. Global FDI inflows in 2009 and 2010 (US\$ billion)

Nevertheless, contrary to those claims, De Propris and Driffield (2006) find that "FDI generated clusters have proven to be fragile and short-term: the MNE does not embed itself in the locality but simply relocates if economic conditions change; there is no or little technology transfer and, finally, if there spin-offs from the MNE, these trend to be sub-contractors for whom the MNE is the only buyer. The outcome is a monopsonistic cluster, whose survival depends on the MNE”. (De Propris and Driffield, 2006: 281)

With the adoption of pro-market policies by the MERCOSUR member countries (Note 5) (i.e. Argentina, Brazil, Paraguay and Uruguay) capital inflows have increased. For instance, the inflow of capital rose from $1.4 \%$ in 1984-89 to 5.9\% in 1997-99. In addition foreign corporations have become an important source of capital inflows. (Chudnovsky and Lopez, 2004) In Argentina and Brazil, the regulatory regime of import substitution industrialisation (ISI), was replaced by pro-market polices with MNEs playing a prominent role. Chudnovsky and Lopez, (2004) argue that 'The strategies of foreign corporations seem to be derived from an 'eclectic paradigm' of FDI, primarily motivated by efficiency seeking, resource seeking, strategic asset seeking and market seeking. However, for instance, MERCOSUR affiliates rarely undertake R\&D or product and process design activities, since these functions are centralised in their parent company or in affiliates located in developed countries". (Chudnovsky and Lopez, 2004:645). They added, "The FDI boom in MERCOSUR in the 1990s has not yet generated a significant contribution to the enhancement of the competitiveness level and the upgrade of the trade structure of the host countries. In turn, MNE affiliates seemingly have fewer linkages with the local economy (as revealed by their higher import propensity) than domestic firms. Hence, it comes as no surprise to find that, especially in the manufacturing and service sector, significant trade deficits result from their operations in MERCOSUR countries". (Chudnovsky and Lopez, 2004:651)

When global conditions are favourable for the inflow of capital to developing countries, these countries experience a capital surge. It also means that exchange rates and monetary policies have to be favourable to foreign investors. However, if such favourable conditions prevail, this may lead to the accumulation of excess foreign exchange reserves. It would be costly because when the global conditions turn unfavourable for capital flows, the capital flows out, reserves are quickly depleted, leading towards uncertainty in financial markets and economies.

The problem is particularly acute for countries that are more integrated with US financial markets. On the issue of externally driven vulnerability the IMF has recently changed its previously known policies statement. Now it lends support to the national capital control policy of developing countries. Having been critical of countries for selecting such controls in the past, the IMF now seems to have changed its views and realises that such attempts may not be all 
bad. However, its endorsement of such measures has been partial. The IMF report (2010a) makes a case for what it terms capital flow management measures, and recommends them only as a last resort and as a temporary measure.

Many Latin American countries since the 1980s have adopted neo-liberal economic policies which led towards a reduction of tariffs and other protectionist measures, eliminated barriers to FDI, reduced government spending and also promoted the export sector. However, these countries did not experience a rapid increase in growth rates. The average growth rates were less than 2\% per annum between 1986 and 2006 in Latin America, compared to growth of 5.5\% annually between 1960 and 1980 i.e. prior to liberalisation. It was claimed that with the neoliberal policies inflow of capital by MNEs would dramatically increase and would be able to create growth and jobs. It was also said that foreign investors would not only bring technology, management skills and knowledge to the manufacturing sector, but would also create spill overs, which would ultimately improve the skills and technology of the domestic firms. However, twenty five years later, the foreign inflow of capital has fallen short on its promise in the region. Only a few countries such as Argentina, Brazil, Chile, Mexico and Venezuela have in fact received any significant amount of FDI. There is unanimity among researchers that large and growing economies with low levels of inflation are the key determinants of the inflow of capital in the region. (Chudnovsky and Lopez, 2004)

The recent drive towards financial liberalisation in developing countries appears to mean the removal of national governments' restrictions over the mobility of capital. Taking measures to support the internationalisation of finance would mean making "national finance capital" into an integral element of the international finance capital, and at the same time making Central Banks independent removes government control over key policies such as credits, and monetary and exchange rate policy. It means that monetary policy decisions would be removed away from government control into the hands of bureaucrats and financiers. As a result, any dislike of the government's economic policies may result in financial instability and capital outflow, and ultimately adversely affect the overall economy. Therefore, under such circumstances the government simply has to support those polices recommended by the financiers.

In order to fully understand the economies of developing countries the discussion on the existence of surplus-labour is very important. It is often said that the inflow of foreign capital will increase investment and thus will create more jobs. Such an economy consists of two sectors - a relatively small modern sector and a large traditional sector. It is also assumed that the modern sector produces high value commodities, while the traditional sector is engaged in the production of self-consumption goods rather than for markets (Siddiqui, 1998). The wages are relatively higher in the modern sector and it is assumed that transfers would take place from the traditional to the modern sector. In the early years of independence, it was said that colonies were forced into specialisation for the production of primary commodities for exports, while at the same time manufactured goods were imported. This pattern was seen as contrary to the expectations of developing countries. Therefore, an independent policy was needed to meet the aspirations of their people. This is also called an "infant industry argument". The industries in the manufacturing sector of the developing countries needed time and support to mature through "learning by doing" before they could compete with more powerful manufacturers from developed countries. (Chang, 2004)

The role of foreign capital in the economic development of the developing countries needs to be looked at carefully. These countries can be broadly put into two groups: first, a group where domestic savings are not enough to launch the manufacturing sector, also known as saving deficient countries (Note 6). For these countries relying on foreign capital to boost their manufacturing sector could undermine the development process mainly due to foreign capital pre-empting the growth of a domestic capitalist class, who may be in the embryonic stage. The other problem could be that profits earned by foreign investors do not constitute domestic savings and thus could leave the country in a situation which they consider unfavourable. Due to these reasons even in deficient-savings countries foreign capital cannot be relied upon for sustained growth. It seems clear that government intervention is required to steer the allocation of investment between traditional and modern sectors. The successful examples of East Asian countries such as Japan, South Korea, and Taiwan could provide some lessons for developing countries.

In the second group were those where the domestic saving rates are sufficient to launch the manufacturing sector, which can be seen as saving-sufficient countries. It is said by mainstream economists that FDI can supplement domestic saving, but the inflow of foreign capital means the increased availability of foreign capital. Thus, the availability of new technology was seen to be important in order to raise productivity. According to them, such constraints even in saving sufficient countries could prevent the full utilisation of domestic resources. (IMF, 2010b)

Most of the argument in support of foreign capital overlooks the differences between different forms of foreign direct investment. Financing is mainly seen as providing resources for increased levels of investment in the economy. However, this may be useful if a country's economy does not have any idle resources. Then the resources have to be 
obtained from abroad. However, if a country's economic resources are underutilised and at the same time the country is receiving resources from abroad, this may play a negative role and also increase foreign capital dependence.

However, I am not trying to deny the usefulness of foreign capital in a situation where capital is invested into "export processing zones" or "special economic zones" that are insulated from the rest of the economy. Successful Chinese examples from the early 1980s and 1990s could be cited here. The Chinese figure for inward investment does not look exceptionally high i.e. the share of gross investment of nearly 50\% of the Chinese GDP in 2005, with FDI inflows in relation to GDP of 5\%. A large part of this comes from overseas Chinese people (Davies, 2012). In the mid-1990s one-half of the outward inflow of capital was into the services sector. Developed countries like the USA, the UK, Germany and France with strong service sector companies fully support the liberalisation of service sectors in developing countries.

\section{East Asian Experience}

The impressive economic growth and changes in the living conditions of the people witnessed in the East Asian economies in the last nearly five decades is well known and there is no need to elaborate it here. (Amsden, 1989) Remarkable growth took place in Japan starting after the ruin and destruction of the Second World War propelling Japan towards becoming the most successful exporter of manufactured goods, and later on, the largest capital exporter in the world. Japan's successful industrialisation also played a positive role in the economic expansion in South Korea, and in the late 1980s with the appreciation of the Japanese Yen, Japanese capital moved into Malaysia, Thailand, Indonesia and Philippines. Japanese technology and capital played an important role towards industrial expansion in these countries; however, it was not the only factor.

Seven out of the top ten exporting countries (in terms of the rate of growth of export) in 2000 in the world were from East Asia i.e. China, Singapore, South Korea, Malaysia, Thailand, Philippines and Indonesia. These countries were able to transfer substantial resources from their agriculture sectors. They had access to Western markets for their exports reflecting geopolitical reasons and had followed different industrial policies. For instance, City states like Hong Kong and Singapore were 'free ports' and relied heavily on private foreign capital for industrial development. While, Japan, South Korea and Taiwan had the advantage of land reforms, rural development, and universal education which besides creating a more egalitarian basis also increased productivity and output in agriculture (Siddiqui, 2014b).

There is little doubt that the financial liberalisation of the mid-1990s left East Asian countries vulnerable to the mercy of foreign investors. In fact, the large current account deficits and large foreign debts to export ratios may often mean potential crisis could trigger a loss of investor confidence leading towards panic and currency crisis. This situation may put pressure on the host government to adopt austerity programmes to reduce imports and capital flights. With financial liberalisation the businesses were allowed to borrow from global financial suppliers without any obligation to generate the foreign exchange necessary to repay it. Thus, the question arises why was financial liberalisation adopted by East Asian countries who had witnessed high domestic savings and investment rates? East Asian countries had successfully developed the manufacturing export sector, some countries with active government support, and also often supported by international companies. Such alliances increasingly demanded financial liberalisation and financial openness. It was hoped by domestic manufacturers and the policy makers that giving the western financial sector access to their domestic markets, would eventually lead to greater access to western markets for their manufacturing goods.

It is widely agreed now that in East Asia, the industrialisation was largely state led rather than market-led. As Ajit Singh (1995) argues, "the outstandingly successful East Asian economies of not just China, but also Taiwan, South Korea and Japan, the state has played a pivotal role, in a wide variety of ways, in bringing about rapid industrialisation. It has pursued in each of these countries a vigorous and aggressive industrial policy to carry out the required structural transformation of the economy. The government has 'guided' the market, and not followed a hands-off market friendly approach". (Singh, 1995:181) For instance, in South Korea FDI was discouraged in favour of domestic entrepreneurs. Taiwan relied more on foreign capital, but state direction in investment allocation was crucial (Siddiqui, 2013). Japan and South Korea discouraged large-scale foreign direct investment, while favouring local capital accumulation throughout their early phase of industrialisation. For example, inwards FDI in 1995 has amounted to less than $1 \%$ of the gross domestic capital formation in South Korea. However, in Singapore FDI inflow was important, and controlled more than $75 \%$ of the output and $90 \%$ of all manufacturing exports.

In the 1980s industrial expansion in the region of the South-East namely Malaysia, Thailand, Indonesia and the Philippines, relied more on foreign capital for their industrial development and exports. The government always intervened in various ways to set industrial priorities and improve the competitive position of the industry. One 
common feature of these countries is that they all focused on exports and their businesses were provided with support such as subsidies credits, tax concessions etc. to domestic producers against foreign competitors.

In Malaysia, for instance, foreign capital in the 1970-1980 was largely confined to mining and agriculture. However, in the 1980s it started to flow into the manufacturing sector especially in export processing zones. The regime was highly repressive and trade unions and political opposition were almost non-existent. Malaysia is an interesting example, where in order to promote economic transformation and growth, it was said that progressive substitution of primary commodities exports by manufactured exports was the key strategy of the government. (Siddiqui, 2012a)

However, a large part of foreign capital is absorbed within Asia, especially in China. It is often claimed that export success has been due to market-friendly policies adopted by East Asian governments. Such policies also encouraged foreign capital inflows into these economies. Raymond Vernon (1979) argues that trade can become the vehicle for transforming new goods and technology across countries; this is also known as the 'flying geese model'. In his product-life cycle, he claims that some production would be shifted to poor countries from rich countries, as they consistently focus on new products.

China has been the largest recipient of FDI in recent years among the developing countries and is extraordinary on many counts. Along with this China has generated relatively high domestic savings and investment rates. It has launched its pro-market reforms only since the 1980s, but prior to that the country accomplished radical land reforms and a very egalitarian society with an almost complete absence of a domestic capitalist class. State direction has played a key role in launching reforms and directing them at the same time. Peter Nolan (1995) describes FDI in China in the following words: "In the post-Mao period China went to great lengths to attract foreign capital, being able to assure foreign investors of the 'good investment environment' with 'stable social order and cheap labour'. Local governments pushed central government regulations to the limit in order to attract foreign investment. Around three-quarters of the total inflow of capital in the 1980s came from Taiwan and Hong Kong, and were strongly concentrated in the coastal provinces of south-east China, especially Guangdong and Fujian. In addition to direct foreign investment, much overseas capital went into loans to indigenous factories to help them to upgrade their technical level through the import of new technology". (Nolan, 1995: 25)

Since the launching of neo-liberal reforms in China foreign investment has sharply increased, the country has been a major global recipient of foreign capital. Prior to 1979, the FDI in China was negligible, but afterwards it increased rapidly. However, in recent years the FDI has become less important as a proportion of China's GDP. It is often argued that FDI has various benefits for the host country. In the Chinese case, for instance, foreign capital played a positive role in transferring technology, introducing more efficient business management systems and providing the most valuable foreign exchange rates, and finally, providing greater access to foreign markets.

In fact, there is no homogeneous model of developmental policies among the East Asian countries and their experiences are quite different from each other. For instance, Japan and South Korea did not rely on foreign capital. Additionally, inward flows of capital between 1985 and 1996 amounted to less that 1\% of gross domestic capital formation in South Korea and less than $4 \%$ in Taiwan (Siddiqui, 2013). However, Singapore, Hong Kong and most recently China have relied on foreign capital for their industrialisation and development (Siddiqui, 2010a). Overall in most of these countries the government played a critical role in creating a favourable environment for the production of goods and services. 


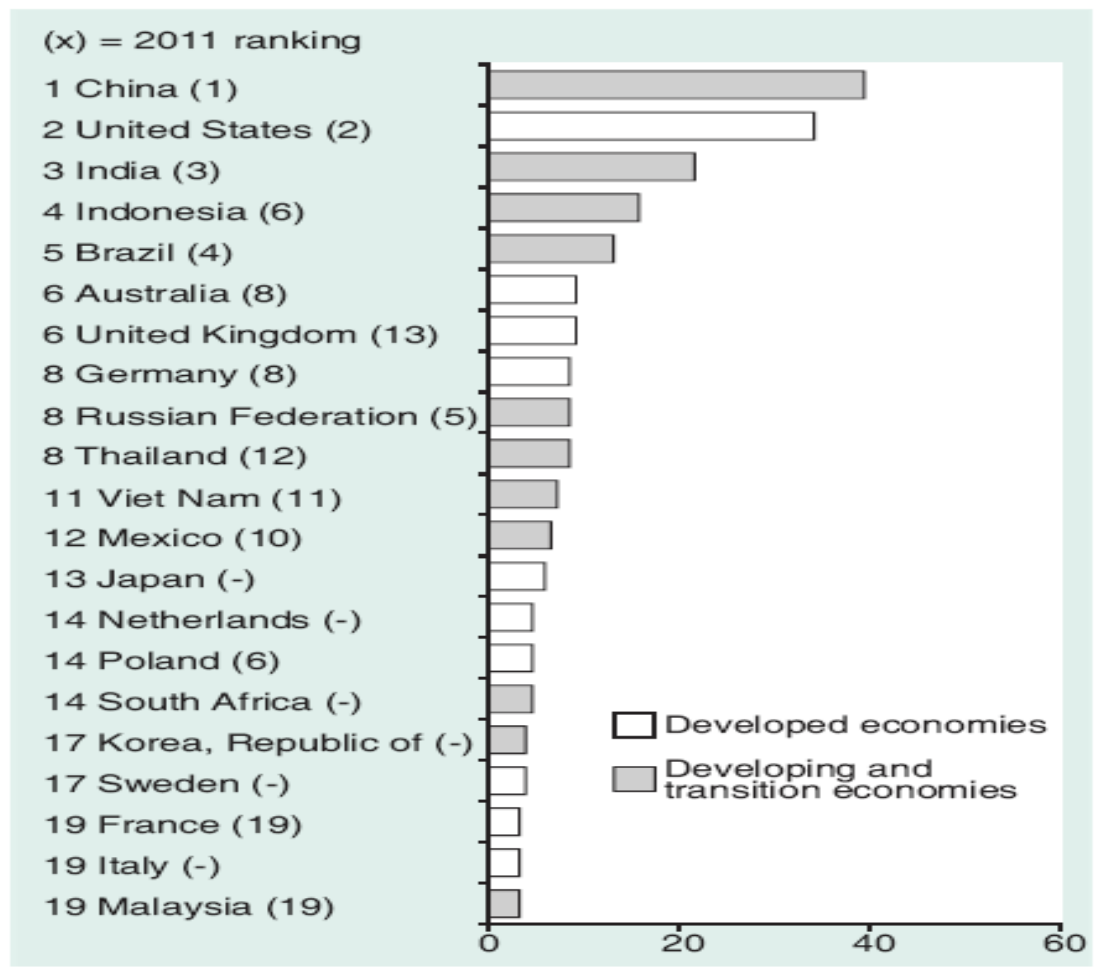

Source: UNCTAD survey.

Note: Based on 174 validated company responses.

Chart 6. MNEs top perspective host economies, 2012

A recent survey by UNCTAD reveals that developing countries are considered by MNEs as highly important. China ranked top, while India also received an important rating as Chart 6 indicates. The rising importance, it seems, does not come at the expense of developed economies. Among the top five, four are developing economies as shown in Chart 6. The perception of foreign investors regarding developing countries has changed since their adoption of neo-liberal policies and these countries are seen as potential and less risky markets. (UNCTAD, 2012)

\section{The Indian Experience}

The question arises why could South Asian countries not successfully launch industrialisation relying on foreign capital inflows? The experiences mainly in the last twenty years show that such inflows of foreign capital were mainly limited to a handful of developing countries and also such foreign investments were highly sensitive to foreign exchange rate fluctuations. Thus, under such a situation it was difficult to build a long term industrialisation strategy. With any potential economic problems, foreign capital is ready to withdraw, leaving the economy with adverse effects in terms of employment and balance of payments situations (Siddiqui, 1994b).

India experienced a severe balance of payments crisis as foreign exchange reserves were reduced to a mere US $\$ 1$ billion in 1991, barely sufficient to pay for one month of imports. The country entered into an IMF led 'Structural Adjustment Programme'. As a part of an agreement, a range of far reaching 'pro-market' reforms were initiated in the trade, industry and finance sectors. As a result, there has been a marked increase in private capital inflows, a trend that is a clear break from the three decades' earlier policies. In the 1960s there was very little FDI in India. Even in the 1980s, the average FDI was around US $\$ 0.2$ billion per year. However, after the adoption of neo-liberal policies, FDI increased in the 1990s and reached its peak in 1996-97 at US\$6 billion and then declined to $\$ 5.3$ billion in 1997-98 (Chakraborty and Nunnenkamp, 2008). However, India was not unique in witnessing this; such trends were observed in several developing countries. It seems that low interest rates in the United States encouraged foreign investors to seek profitable avenues abroad. The total amount of FDI was US\$ 350 billion in 1996, with developing countries receiving \$130 billion. For a vast economy like India, the average \$2-3 billion capital inflow 
per year is not very much, and amounts to less than $5 \%$ of its domestic capital formation. Hence, FDI remains marginal to the country's total investment process (Chakraborty and Basu, 2002; Rao and Dhar, 2011).

After the adoption of pro-market policies in 1991 India's regulation policies towards foreign investors changed dramatically (Siddiqui, 2010b). Currently, foreign firms are permitted a large equity ownership, and can claim and repatriate a large share of domestic profits. They are able to have full protection of their top technology through direct control rather than through patent and licensing agreements. With the new policies, foreign equity caps have been relaxed. I mean here that foreign companies have got greater flexibilities and choices that would affect their future development. Domestic companies choose to sell because it may be too difficult for them to face the competition. Alternatively if domestic companies decide not to sell to foreign partners, the foreign companies can set up their own subsidiaries. Under both situations the industrial landscape in the future will change, with far greater presence of foreign companies than earlier. It could lead towards India merely being the location for multinational companies seeking to produce and cater to large domestic markets and being suppliers of raw materials and skilled labour to the multinational companies.

The important issue of whether FDI contributes to the growth of a host country's industry or not can be verified by examining the spillover gains in the capital goods sector. The spillover is supposed to take place in the host country in a number of ways, such as creating higher efficiency, transfer of technology and greater access to export markets. Regarding this question, the recent findings a by Jadhav and Reddy (2013) about India's experience since adopting neoliberal reforms in 1991, is quite interesting. As the study observes, "the spillover effects are very slow to be realised and higher benefits from FDI have accrued to foreign firms. We do not find support for FDI as one of the key drivers for industrial growth in the capital goods sector as claimed by the industry caption". (Jadhav and Reddy, 2013: 59) Further economic reforms are supposed to attract higher levels of FDI in the aviation sector, insurance, pensions and multi-brand retailers in India. The FDI enthusiasts are demanding further changes in FDI limits in industries where it still has got certain restrictions. It is also claimed that the spillover effect will benefit domestic firms. This would increase the availability of capital and new technology, which is supposed to help domestic firms to raise efficiency and productivity. (Ray and Venaik, 2008) However, such claims ignore the effect on competition, as foreign firms with their greater access to capital, technology and other resources, could result in the exit of domestic firms.

Jadhav and Reddy's (2013) study points out crucial facts on FDI in India. According to them, "The contribution of foreign investment (FDI and foreign institutional investment both) to the gross fixed capital formation (GFCF) of the country is an average around $7 \%$ over the last 20 years and around $9.7 \%$ in the past 10 years. It is clear that rather than FDI, it is domestic investors (households as well as industry) who substantially contribute to GFCF in India". (Jadhav and Reddy, 2013: 60) Another study by Kuntluru et al (2012) discussed the impact of foreign investment on the export performance of the pharmaceutical industry in India. They found the negative impact of foreign ownership on export performance. Their study concludes that foreign firms are more interested in focusing on the domestic market rather than the export market. Also Ray and Venaik's (2008) study on the contribution of foreign firms to the development of host countries through the development of export orientation and royalties, finds that the contributions of foreign firms to the increase in exports and royalties in the host countries are much lower when compared to the contribution of domestic firms to the developing countries.

Malik et al (2012) discuss the link between FDI and foreign companies and spillover effects in developing countries. Their study found that competitive advantages available to the foreign companies, if compatible with the local industry structure, results in either spillover effects or negative competition effects. Moreover, in an analysis of the effect of FDI on the development of the host country resulting from the spillover effects of foreign investment, another study by Gorg and Greenaway (2004) did not find any significant empirical evidence to support the spillover effects.

It seems that there is a need to avoid the excessive liberalisation of foreign capital inflows, especially hot money. India's policy stance towards foreign capital is considerably more liberal than in the past, but still restrictive, for instance, with respect to inflows of short-term credit. Moreover, in India, rather than abandoning the state role, we need a far sighted, more imaginative developmental policy capable of mobilising and allocating resources on the necessary scale (Siddiqui, 2015). Capital accumulation is crucial to investment and to raise productivity. However, the Indian situation is different as observed by Prabhat Patnaik, "Under the logic of liberalization the state begins to withdraw from the role of a principal player in the arena of production itself. As a result, 'liberalization' leaves the economy without any agency capable of transforming potentially investible resources into actual productive investment, i.e. capable of using the slack in the economy to step up its rate of growth" (Patnaik, 1995: 226) 
In recent years, one important issue which has drawn less attention in the academic literature is corruption in the host country. It seems that corruption does not deter FDI inflows. For instance, Brazil, China, India, Mexico and Thailand attract large capital inflows despite these countries being perceived to be highly corrupt (Heidenheimer and Johnston, 2002). With the increased levels of trade and investment, it is important to briefly examine the issue of corruption here. Corruption is important to examine because it produces bottlenecks, inefficiencies, and increases costs. Corruption is defined in various ways. The United Nations defines corruption with "improbity", which encompasses not only that it is illegal, but also improper. The study by Bardhan (1997) has shown the adverse effects of corruption on capital inflows in the context of the cost of doing business in developing countries, since foreign companies have to pay extra in the host country to bribe officials in order to overcome red tape, licenses or government permission to invest. Bribes and corruptions raise the cost of production. It said that such additional costs decrease the expected profitability of investment, and corruption is seen to undermine a company's profitability. (Bardhan, 1997)

In India in the early 1990s, the neoliberal policy was accompanied by a stock market boom and a rise in share prices, which was seen as the proof of success for the neoliberal policies. The stockbroker Harshad Mehta was depicted as a "financial wizard". However, by 1992, it was known that Mr. Mehta had engineered much of this price rise through fraud. The mechanism was the agreement to sell and purchase securities at higher prices after a period of time. These options are open to banks in their dealings with each other, in fact, the securities did not change hands at the time of dealing and a bank receipt was assured by the purchasing bank that securities existed. Mehta saw that some banks were ready to issue receipts on non-existence securities for the payment of a fee. When the scam was exposed the share prices collapsed. (Siddiqui, 2010b) However, when the truth came out, among the leading investors in the Mehta group was the commerce minister Mr. Chidambaram's wife: the minister was forced to resign. Recently immense corruption was revealed in the revelations of the $2 \mathrm{G}$ scam scandal, involving the communication minister Mr. Raja. It is believed to have cost the country hundreds of millions of dollars. The neoliberal policies were created for the transfer of public property to private entrepreneurs. The recent scams such as the $2 \mathrm{G}$ spectrum, Commonwealth Games, the Coal allotment etc. have brought to the surface the issue of corruption in India.

\section{Concluding Remarks}

The proponents claim that the overall increase in foreign capital inflows during the last decade has been due to the adoption of neoliberal policies by developing countries. The reason for this is that foreign investors who experienced easy monetary conditions because of expansion policies followed by the central banks, found the developing countries to be more profitable and less risky than their own markets in developed countries. Such capital inflows cannot be expected to continue unabated.

However, the actual experience of the last-twenty five years, when many developing countries brought down capital account restrictions and cross border movements, is very different. Greater amounts of capital inflow went to high saving rather than low saving developing countries. For instance, during the last decade, sub-Saharan Africa and most of the Latin American countries received smaller amounts of foreign capital, while the high saving countries of East Asia received higher amount of inflow of foreign capital, especially south-east Asian countries. For instance, Japan and South Korea did not rely on foreign capital, whereas Singapore and Hong Kong and most recently China have relied on foreign capital for their industrialisation and development (Siddiqui, 2010a).

All these indications are quite contrary to the current recommendations of the international institutions in support of the free flow of capital and the opinion that foreign investment should be treated on a par with domestic businesses. As Ghosh (2012) observes, "Policy makers across the world have been preoccupied with appeasing large capital generally and financial markets in particular, in the belief that this is the main way to ensure faster rates of GDP growth and therefore job creation. Now we know that such a strategy tends to be counterproductive, especially when it also involves fiscal austerity in the midst of a recession". (Ghosh, 2012) Also Lall and Narula (2004) observe that, "Market forces cannot substitute for the role of governments in developing and promoting a proactive industrial policy. MNEs and FDI may well lead to an increase in productivity and exports, but they do not necessarily result in increased competitiveness of the domestic sector or increased industrial capacity, which ultimately determines economic growth in the long run". (Lall and Narula, 2004: 461)

It was found that in order to avoid their export prices becoming un-competitive the developing countries have to guard against appreciation of their currencies and also against high inflation. It is clear from the experiences of sub-Saharan Africa and other developing countries, that with low domestic savings rates, they would find it difficult to achieve rapid economic growth rates even with foreign capital inflows. By allowing the unrestricted inflow of foreign capital, these countries can undermine their own domestic investors, lend their own savings to developed countries and increase their dependence on foreign investors to sustain higher economic growth rates. Therefore, it 
seems clear that control over capital flows is quite a crucial economic policy option for many developing countries and for their economic sovereignty.

My findings point out that the issue of capital inflows in developing countries must be seen within the context of neoliberal economic reforms. Developed countries (in the name of openness and globalisation) are trying to legitimise capitalist relations and also to legitimise social and economic problems of dependency that capitalism may bring (Siddiqui, 2012b). As accumulation becomes more global, developed countries require laws to protect private property and investment, and also harmonisation of laws, regulation and institutions that govern financial markets.

In fact, India needs to formulate strategies such as selective government support to some manufacturing industries over others. Specifically government intervention with the aim to shift the economy towards higher value added activities will be impossible to accomplish on the basis of neo-liberal economic polices. Critics might call it "picking winners" and argue that it generates rent-seeking behaviour and may also be seen as wasting public resources and undermining efficiency. Recently, Brazil has started such an intervention. For instance, the Brazilian Development Bank (BNDES) is playing a critical role in such changes. Due to state intervention and support, some of the country's internationally competitive industries have emerged in recent years. The government allocated more funds for investment to poorer regions and as a result, Brazil was able to achieve higher and balanced growth rates even after the 2008 global recession period.

Investors of foreign capital, whether in the form of portfolio or direct investment, will be concerned about the economic performance of the capital-importing countries. Then it becomes important that the so-called sound macroeconomic policies are seen as reducing the degree of uncertainty surrounding investment decisions. Higher rates of inflation, low economic growth and over-valued exchange rates and current account deficits will most likely make countries unattractive to foreign capital. The argument above seeks to establish that rapid growth could be fragile, besides the fact that growth driven by dependence to capital inflows, especially financial inflows is vulnerable because of the possibility that such inflows can stop and capital outflows could occur, including for reasons beyond the control of the host country.

We do not underestimate the importance of FDI and exports, but the role of government and institutions are important for a successful outcome. Nevertheless, an extension of complete or unquestionable protection to the domestic industries is not the way forward, but a step by step openness and a combination of threat of competition and rewards will most likely lead towards a successful outcome. This policy will have a significant effect on economic development and stability, job creation and the reduction of poverty levels in developing countries.

\section{Acknowledgements}

The author would like to thanks Phil Armstrong and Hugo Radice for helpful comments and suggestions on an earlier version of this paper. The author would also like to thank the two anonymous referees for their valuable comments, which has helped to sharpen my arguments.

\section{References}

Alfaro, L., Chanda, A., Kalemli-Ozcan, S., \& Sayek, S. (2004). FDI and Economic Growth: The role of local financial markets. Journal of International Economics, 64, 89-112. http://dx.doi.org/10.1016/S0022-1996(03)00081-3

Amsden, A. (1989). Asia's Next Giant. New York: Oxford University Press.

Bardhan, P. (1997). Corruption and Development: A Review of Issues. Journal of Economic Literature, 25, 1320-1346.

Calvo, G., Leiderman, L., \& Reinhart, C. (1993). Capital Flows and Real Exchange Rate Appreciation in Latin America. IMF Staff Papers, 40(1), 108-151.

Chakraborty, C., \& Basu, P. (2002). FDI and Growth in India. Applied Economics, 34(9), 1061-1073.

Chakraborty, C., \& Nunnenkamp, P. (2008). Economic Reforms, FDI and Economic Growth in India. World Development, 36(7), 1192-1212

Chang, H.J. (2004). Regulation of Foreign Investment in Historical Perspective. The European Journal of Development Research, 16(3), 687-715. http://dx.doi.org/10.1080/0957881042000266660

Chang, H.J. (2006). The East Asian Development Experience: The Miracle, the crisis and the future. New York: Zed Books. 
Chudnovsky, D., \& Lopez, A. (2004). Transnational corporations' strategies and foreign trade patterns in MERCOSUR countries in the 1990s. Cambridge Journal of Economics, 28(5), 635-652. http://dx.doi.org/10.1093/cje/beh029

Davies, K. (2012). Inward FDI in China and its Policy Context, Columbia University. Retrieved from http://hdl.handle.net/10022/AC:P:15269 Series

De Propris, L., \& Driffield, N. (2006). The Importance of Clusters for Spill overs from Foreign Direct Investment and Technology Sourcing. Cambridge Journal of Economics, 30(2), 277-291. http://dx.doi.org/10.1093/cje/bei059

Ghosh, J. (2012). Why profit-led growth is a myth. The Guardian, February $14^{\text {th }}$, London.

Girdner, E.J., \& Siddiqui, K. (2008, Jan-June). Neoliberal Globalization, Poverty Creation and Environmental Degradation in Developing Countries. International Journal of Environment and Development, 5(1), 1-27.

Gorg, H., \& Greenaway, D. (2004). Much Ado about Nothing? Do Domestic Firms Really Benefits from Foreign Investment?. The World Bank Research Observer, 19, 171-197.

Heidenheimer, A.J., \& Johnston, M. (2002). Political Corruption ( $3^{\text {rd }}$ ed.). New Jersey: Transaction Publishers.

IMF. (2010a). Research Department's paper, Feb. Washington D.C.: IMF.

IMF. (2010b). World Economic Outlook. Recovery, Risk and Rebalancing, Washington D.C.: IMF.

Jadhav, A.M., \& Reddy, V.N. (2013). Does FDI contributes to growth? Evidence from the capital goods sector in India. Economic and Political Weekly, XLVIII(12).

Kuntluru, S., Mupani, V.P., \& Khan, M.A.A. (2012). FDI and Export Performance of the Pharmaceutical Firms in India. International Journal of Economics and Finance, 4, 216-226.

Lall, S., \& Narula, R. (2004). FDI and its Role in Economic Development: do we need a new agenda?. The European Development Research, 16(3), 447-464.

Malik, M.A.R., Chaudhry, A.R., \& Ashraf, M. (2012). Exploring the Link between FDI, MNEs and Spillover Effects in the Developing Economies. International Journal of Business and Management, 7, 230-240.

Michie, J. (2011). The Handbook of Globalisation ( $2^{\text {nd }}$ ed.). Ma USA: Edward Elgar.

Nolan, P. (1995). Politics, Planning and the Transition from Stalinism: The Case of China. In Chang, Ha-Joon and Rowthorn, Robert (Eds.), Role of State in Economic Change. Oxford: Oxford University Press.

OECD. (2006). Glossary of Statistical Terms. Paris: OECD.

Patnaik, P. (1995). Investment and Growth in a liberalised Economy. In Patnaik, Prabhat (Ed.), Whatever Happened to Imperialism and Other Essays. New Delhi: Tulika Publishers.

Rao, K.S.C., \& Dhar, B. (2011). India's FDI Inflows Trends and Concepts. New Delhi: Institute for Studies in Industrial Development.

Ray, P.K., \& Venaik, S. (2008). Foreign Ownership and Subsidiary Performance: Impact on Research and Export. Economic and Political Weekly, 43, 57-65.

Siddiqui, K. (1994a). The Economic Philosophy of Neo-liberalism. The Nation, 20th September.

Siddiqui, K. (1994b). Evaluating the Pro-Market Economic in India. The Nation, 3rd \& 4th December.

Siddiqui, K. (1998). The Export of Agricultural Commodities, Poverty and Ecological Crisis: A Case Study of Central American Countries. Economic and Political Weekly, xxxiii(39), September 26 ${ }^{\text {th }}$, A128-A137.

Siddiqui, K. (2009, March). The Political Economy of Growth in China and India. Journal of Asian Public Policy, 1(2), 17-35. http://dx.doi.org/10.1080/17516230902734528

Siddiqui, K. (2010a). The Political Economy of Development in Singapore. Research in Applied Economics, 2(2), $1-31$.

Siddiqui, K. (2010b). Globalisation and Neo-liberal Economic Reforms in India: A Critical Review. In Pramanick, S.K. and Ganguly, R. (Eds.), Globalization in India: New Frontiers and Emerging Challenges. New Delhi: Prentice Hall.

Siddiqui, K. (2012a, November). Malaysia's Socio-Economic Transformation in Historical Perspective. International Journal of Business and General Management, 1(2), 21-50. 
Siddiqui, K. (2012b, December). Developing Countries Experience with Neoliberalism and Globalisation. Research in Applied Economics, 4(4), 12-37. http://dx.doi.org/10.5296/rae.v4i4.2878

Siddiqui, K. (2013, December). Experiences of Developmental State in India and Taiwan. Journal Think India, 16(4), New Delhi, 91-121

Siddiqui, K. (2014a, April-June). Growth and Crisis in India's Political Economy from 1991 to 2013. International Journal of Social and Economic Research, 4(2), 84-99. http://dx.doi.org/10.5958/2249-6270.2014.00487.5

Siddiqui, K. (2014b). Higher Education in the Era of Globalisation. International Journal of Humanities and Social Science, 3(2), 9-32.

Siddiqui, K. (2015). Agrarian Crisis and Transformation in India. Journal of Economics and Political Economy, 2(1), 3-22. http://dx.doi.org/10.1453/jepe.v2i1.122

Singh, A. (1995). The State and Industrialization in India. In Chang, Ha-Joon and Rowthorn, Robert (Eds.), Role of State in Economic Change. Oxford: Oxford University Press.

Tourk, K. (2012). Financial Times. Letter to the Editor, $10^{\text {th }}$ March, London.

UNCTAD. (2001). World Investment Report. Geneva, United Nations.

UNCTAD. (2012). World Investment Report, Geneva, United Nations. Retrieved from www.unctad-docs.org/UNCTAD-WIR2012-Full-en.pdf

Vernon, R. (1979). The Product Cycle Hypothesis in a New International Environment. Oxford Bulletin of Economics and Statistics, 41(4).

Wilkins, M. (1989). The History of Foreign Investment in United States to 1914. Cambridge, MA: Harvard University Press.

World Economic Outlook. (2011). IMF, April, Washington D.C.: IMF.

\section{Notes}

Note 1. 'Developing countries' are defined where the average income is much lower than in industrial nations, where agriculture predominates the economy. Most of them are in Africa, south Asia, and Latin America. (See OECD, 2006, Glossary of Statistical Terms, Paris: OECD)

Note 2. The 'developed economy' typically refers to a country with a relatively high level of income and productivity. The most common criteria for evaluating a country's degree of development are per capita income or gross domestic product (GDP), level of industrialization and general standard of living. The most well-known current examples of developed countries include the US, Canada, and most of Western Europe and Japan. (see OECD, 2006)

Note 3. See Girdner and Siddiqui, 2008

Note 4. I bid. see Chang, 2004:696

Note 5. These MERCOSOR member countries adopted 'Structural Adjustment Programmes' i.e. market deregulation, privatisation of state enterprises, and liberalisation of trade and capital flows on the recommendations of IMF/World Bank also known as the 'Washington Consensus'.

Note 6. Saving-deficiency refers to a situation where the domestic saving rates are below the minimum requirement, which makes the launching of development feasible. 